\title{
O CARÁTER PUNITIVO DA RESPONSABILIDADE CIVIL E DANOS MORAIS COLETIVOS NA SOCIEDADE CONTEMPORÂNEA: PARA UMA NOVA PERSPECTIVA DE FINALIDADE AO RESSARCIMENTO
}

\author{
Ana Cláudia Corrêa Zuin Mattos do Amaral ${ }^{1}$ \\ Gabriela Stefania Batista Ferreira ${ }^{2}$
}

\begin{abstract}
Resumo: Analisa o dano moral coletivo de modo a verificar a possibilidade de a responsabilidade civil brasileira adquirir como nova perspectiva de finalidade a função punitiva e não apenas a reparatória-compensatória. Para tanto, partiu-se do método hipotéticodedutivo e, mediante revisões bibliográfica e jurisprudencial, demonstra-se que a aplicação da pena civil, enquanto sanção punitiva com fins preventivos em face de lesões a direitos e interesses legítimos transindividuais, manifesta-se possível no Brasil, podendo-se mostrar hábil à inibição de ofensas que acarretem em dano moral coletivo, assim como meio de advertir os potenciais agentes ofensores sobre a rigorosa punição pela reiteração da conduta.
\end{abstract}

Palavras-chave: Indenização punitiva; Função punitiva; Dano moral coletivo; Responsabilidade Civil.

\section{THE PUNITIVE CHARACTER OF THE CIVIL LIABILITY AND MORAL DAMAGE COLLECTIVES IN CONTEMPORARY SOCIETY: FOR A NEW PERSPECTIVE OF PURPOSE TO COMPENSATION}

\begin{abstract}
Analyzes the moral damage collectives in order to verify the possibility of civil liability in Brazil purchase as a new perspective of purpose the function punitive and not just the reparatory-compensatory. It was hypothetical-deductive method and, through a literature review and case law, demonstrates that the application of the civil penalty, while punishment punitive damages for preventive purposes in the face of injury to the transindividual rights and legitimate interests, manifests itself as possible in Brazi, being able to show skillful to inhibition of offenses that give rise to moral damage collectives, and to censor the potential agents of injury.
\end{abstract}

Keywords: Punitive damages; Punitive function; Damage moral collective; Civil Liability.

\footnotetext{
${ }^{1}$ Doutora em Direito das Relações Sociais, Área de Concentração em Direito Civil Comparado pela PUC-SP. Mestrado em Direito Negocial (2002) e Graduação em Direito (1989) pela Universidade Estadual de Londrina. Professora do Programa de Mestrado em Direito Negocial e do Curso de Graduação e Pós Graduação em Direito da Universidade Estadual de Londrina. Professora Colaboradora-Convidada do Curso de Pós Graduação em Direito Civil Contemporâneo do Instituto Brasileiro de Estudos e Pesquisas Sócio-Econômicas. Experiência na área do Direito, com ênfase em Teoria Geral do Direito Civil, Direito Civil Constitucional, Responsabilidade Civil e Biodireito. Coordenadora da Revista Eletrônica de Direito Privado da UEL. Membro da Comissão Coordenadora Geral do Congresso de Direito da Universidade Estadual de Londrina. Vice Coordenadora do Programa de Mestrado em Direito Negocial- UEL

${ }^{2}$ Bolsista CAPES (2016) de Mestrado em Direito Negocial pela Universidade Estadual de Londrina. Pósgraduanda em nível de especialização em Direito do Estado, com ênfase em Direito Constitucional, pela Universidade Estadual de Londrina. Bacharela em Direito pela Pontifícia Universidade Católica do Paraná Campus Londrina (2015). Membro do Grupo de Pesquisa "Autonomia privada, direitos humanos e fundamentais: em defesa da dignidade e concretização da tutela da pessoa por meio da responsabilidade civil". Advogada no contencioso cível e trabalhista. Estudante na linha de pesquisa em Direito Negocial, Responsabilidade Civil e Direitos Humanos e Fundamentais. Interesse em pesquisas no segmento de Direito Civil, Direito Civil Constitucional, Direito Constitucional e Mediação de conflitos.
} 


\section{INTRODUÇÃO}

Marcado por múltiplos impasses na doutrina e jurisprudência, o dano moral coletivo, não raro, recebe críticas acerca de sua pertinência, notando relevante indefinição jurídica pelos intérpretes do Direito que perpassam tanto pela impropriedade de sua denominação quanto pela adequada aplicabilidade do instituto da Responsabilidade Civil.

No contexto de evolução social que remete à configuração contemporânea e globalizada de sociedade, a viabilidade da discussão a respeito dos direitos transindividuais e, por decorrência, de sua salvaguarda faz o Direito repensar seu papel de agente protetor de interesses que não somente abarcam um ser individualizado, mas também uma coletividade.

Com isso, este estudo, o qual parte da compreensão de que se vive hoje um mundo multinacionalizado e, por isso, dá-se margens a lesões de diversas feições, visa identificar se o caráter punitivo das indenizações por dano moral coletivo, como pena civil, possui em território pátrio espaço para acertadamente se desenvolver e propiciar novo panorama às finalidades da responsabilidade civil. Não se restringindo, assim, à reparatória-compensatória, vez que a tutela aos direitos e interesses legítimos transindividuais merecem diferencial tratamento e, perante a reiteração das práticas negativamente exemplares dos potenciais agentes da lesão, a sanção punitiva com fins preventivos capacitaria inibir essa manutenção.

O trabalho analisa, ainda, a pertinência e a possibilidade de se instituir a função punitiva na responsabilidade civil diante do surgimento de novas e variadas espécies de danos, avançando, posteriormente, para a análise da função punitiva do dano moral coletivo enquanto tipo autônomo de dano na ordem jurídica brasileira.

Aprecia-se, também, os danos punitivos, expressão aqui operada como sinônima de indenização punitiva, em que se perscrutará o respectivo desdobramento no ordenamento jurídico nacional e, referenciando-se ao modelo do common law, será feito um exame junto ao direito comparado. Por fim, busca-se investigar a conveniência da aplicação da pena civil por intermédio da ressarcibilidade no dano moral coletivo, porque se liga a defesa de direitos transindividuais e se verifica se a função punitiva do instituto oportunizaria a eficaz correção dos responsáveis pelas condutas danosas, bem como a interrupção da concretização de outras.

Para o alcance dos desígnios propostos, realiza-se a pesquisa com base no método hipotético-dedutivo e, mediante revisões bibliográfica e jurisprudencial, compôs-se uma análise exploratória com o objetivo de desvendar a possibilidade de aplicação de uma sanção 
civil em face do agente responsável pelas condutas lesivas aos direitos transindividuais, por intermédio do dano moral coletivo.

\section{NOVOS PARADIGMAS DE RESSARCIBILIDADE NA RESPONSABILIDADE CIVIL DIANTE DO DESPERTAR DAS NOVAS ESPÉCIES DE DANOS}

A caracterização do Direito como instituição social organizada para reger as relações humanas liga-se diretamente à existência dos conflitos de interesses, sendo a responsabilidade civil uma das ferramentas hábeis à promoção da tutela humana em face de certas práticas sociais consideradas como reprováveis.

Tradicionalmente, contempla-se a responsabilidade civil como o dever de reparar ou compensar um dano material ou imaterial decorrente de conduta, comissiva ou omissiva, ou do risco de determinada atividade que viole direitos de outrem, objetivando a restauração do status quo ante de maneira a restabelecer o equilíbrio social ${ }^{3}$.

A noção de responsabilidade civil, para Gustavo Tepedino (2004, p. 191.192):

[...] visando ao atendimento das finalidades essenciais de justiça e segurança [...] relacionava-se [...] com o princípio elementar de que o dano injusto, ou seja, o dano causado pelo descumprimento de dever jurídico, deve ser reparado.

Sérgio Cavalieri Filho (2012, p. 2), ao correlacionar a concepção de responsabilidade civil com a de dever jurídico originário e sucessivo ${ }^{4}$, pontua que, etimologicamente, revela-se a ideia de obrigação, de encargo. No âmbito jurídico, sua essência,

[...] está ligada à noção de desvio de conduta, ou seja, foi ela engendrada para alcançar as condutas praticadas de forma contrária ao direito e danosas a outrem. Designa o dever que alguém tem de reparar o prejuízo decorrente da violação de um outro dever jurídico. Em apertada síntese, responsabilidade civil é um dever jurídico sucessivo que surge para recompor o dano decorrente da violação de um dever jurídico originário 5 .

\footnotetext{
3 À vista de Sérgio Cavalieri Filho (2012, p. 14): “O dano causado pelo ato ilícito rompe o equilíbrio jurídicoeconômico anteriormente existente entre o agente e a vítima. Há uma necessidade fundamental de se restabelecer esse equilíbrio, o que se procura fazer recolocando o prejudicado no status quo ante”.

${ }^{4}$ Sérgio Cavalieri Filho (2012, p. 2), sobre os deveres jurídicos originário e sucessivo: A violação de um dever jurídico configura o ilícito, que, quase sempre, acarreta dano para outrem, gerando um novo dever jurídico, qual seja, o de reparar o dano. Há, assim, um dever jurídico originário, chamado por alguns de primário, cuja violação gera um dever jurídico sucessivo, também chamado de secundário, que é o de indenizar o prejuízo. A título de exemplo, lembramos que todos têm o dever de respeitar a integridade física do ser humano. Tem-se, aí, um dever jurídico originário, correspondente a um direito absoluto. Para aquele que descumprir esse dever surgirá um outro dever jurídico: o da reparação do dano.

${ }^{5}$ Em resumo, Sérgio Cavalieri Filho (2012, p. 15) explana: “[...] a responsabilidade tem por elemento nuclear uma conduta voluntária violadora de um dever jurídico [...]".
} 
Norteando-se pelo princípio da neminem leadere, haverá responsabilidade se acontecer de um sujeito causar dano ao outro, patrimonial ou extrapatrimonial, incorrendo, por isso, no dever de restabelecer o bem jurídico violado ao estado em que antes estava ou, diante da impossibilidade da restituição, uma compensação à vítima proporcionar (DINIZ, 2001, p. 34).

As indenizações associadas à conservação do staus quo ante ou à compensação pelo prejuízo causado à vítima configura o atual cenário da responsabilização civil. Contudo, perante a presente configuração de sociedade a qual facilita a consumação de diferenciados tipos de danos, o incentivo à adoção das demais finalidades do instituto pode proporcionar um mais justo e integral ressarcimento. Assim se fundamenta, vez que a premissa do direito privado não mais se norteia pelo “[...] direito do homem sozinho, centrado numa hipotética auto-regulamentação de seus interesses privados [...]" (FACHIN, 2000, p. 324).

Por oportuno, tem-se em Sérgio Cavalieri Filho (2012, p. 14) que: "O anseio de obrigar o agente, causador do dano, a repará-lo inspira-se no mais elementar sentimento de justiça". Quando ocorre a violação de um direito ou interesse legítimo de um indivíduo por conduta lesiva de alguém, rompe-se com a harmonia e equilíbrio social. Buscando-se pela responsabilidade civil, a restauração da ordem corrompida pelo dano, vê-se nas funções reparatória-compensatória a regra geral do instituto.

Verificava-se, em remoto tempo, o ressarcimento com base na ação do agente ofensor em que se evidenciava a preocupação do ordenamento dirigida à aferição de culpabilidade. Em contrapartida:

A constitucionalização do direito dos danos impôs, como se viu, a releitura da própria função primordial da responsabilidade civil. $O$ foco que tradicionalmente recaía sobre a pessoa do causador do dano, que por seu ato reprovável deveria ser punido, deslocou-se no sentido da tutela especial garantida à vítima do dano injusto, que merece ser reparada (MORAES, 2006a, p. 245).

Nessa esteira, considerando os contemporâneos anseios sociais, o clássico paradigma da responsabilidade civil, muitas vezes, não atende às pretensões do ofendido quanto à ressarcibilidade aos variados tipos de danos oriundos especialmente do intenso avanço tecnológico e biotecnológico. Esse contexto remete à reflexão acerca da adoção de medidas capazes de prevenir potenciais comportamentos ofensivos ensejadores de responsabilização civil. 
É justamente nessa conjuntura que a função punitiva merece destaque. Ao representar inovação:

A indenização punitiva [...] surge como reflexo da mudança de paradigma da responsabilidade civil e atende a dois objetivos bem definidos: a prevenção (através da dissuasão) e a punição (no sentido de redistribuição) (CAVALIERI FILHO, 2012, p. 106).

Conforme oportunamente se aborda adiante, em que pese a doutrina reconhecer o caráter punitivo das indenizações, sobretudo no tocante aos danos morais ${ }^{6}$, ainda se localiza certa resistência doutrinária ${ }^{7}$ quanto à aplicabilidade no ordenamento pátrio, em que: "A principal razão alegada [...] é o fato de não termos regra escrita que preveja expressamente essa espécie de sanção [...]”' (CAVALIERI FILHO, 2012, p. 106).

Ocorre que, ante a situações fáticas as quais o ressarcimento do dano mostra-se ínfimo em relação à vantagem obtida pelo próprio agente da lesão, a imposição de uma pena exemplar ao mesmo que consista na redução de seu patrimônio (MORAES, 2009b, p. 219) pode ser reconhecida como importante e admissível, tendo em vista as novas tendências da responsabilidade civil.

Frisa-se, ademais, que um dos resultados do processo de constitucionalização do direito privado foi o consequente aumento de espécies de danos surgidos em virtude, também, de um mundo contemporâneo e globalizado. Avista-se isso pois: "A Constituição de 1988, ao erigir a dignidade da pessoa humana como valor fundamental, assegurou proteção a todos os interesses existenciais que componham tal noção" (SCHREIBER, 2005a, p. 14).

Ao consagrar a dignidade como um dos fundamentos do nosso Estado, “[...] a Constituição deu ao dano [...] uma nova feição e maior dimensão, porque a dignidade humana nada mais é do que a base de todos os valores morais [...]" (CAVALIERI FILHO, 2012, p. 88). Destaca-se, semelhantemente, os direitos transindividuais, pois se tornou imprescindível

\footnotetext{
${ }^{6}$ Sérgio Cavalieri Filho (2012, p. 106-107), acerca da indenização punitiva: "Doutrina e jurisprudência, com respeitosas exceções, admitem hoje o caráter punitivo do dano moral, pelo menos em determinadas circunstâncias. [...] A indenização punitiva do dano moral deve ser também adotada quando o comportamento do ofensor se revelar particularmente reprovável - dolo ou culpa grave - e, ainda, nos casos em que, independentemente de culpa, o agente obtiver lucro com o ato ilícito ou incorrer em reiteração da conduta ilícita".

${ }^{7}$ Vide em: MORAES, Maria Celina Bodin de. Danos à pessoa humana: uma leitura civil-constitucional dos danos morais. Rio de Janeiro: Renovar, 2009, p. 227, e SCHREIBER, Anderson. Novos paradigmas da responsabilidade civil: da erosão dos filtros de reparação à diluição dos danos. 5. ed. São Paulo: Atlas, 2013, p. 211.217.
} 
conferir prestações jurisdicionais que a eles garantissem a devida salvaguarda, posto que danos como o dano moral coletivo e o dano social são autênticos tipos autônomos de danos ${ }^{8}$.

A dimensão jurídica privada incidiu em diversas transformações pósconstitucionalização, não trilhando distante a responsabilidade civil. Para além da releitura de seus clássicos conceitos, uma reanálise quanto às suas funções nas conjunturas atuais precisa ser estimulada para que o ressarcimento não perca sua eficácia quando da solução do caso concreto, "[...] não só reparatória, mas ainda preventiva é a missão da sanção civil [...]" (BITTAR, 1999, p. 121).

A dinamicidade da sociedade, ao passo que se consolida, desperta no Direito a necessidade de nela se enquadrar sob o risco de quedar obsoleto e cessar o caráter instrumental à perpetração da ordem e harmonia social. A expansão das diferentes espécies de danos exemplifica os comprometimentos advindos de uma comunidade pós-moderna, consistindo o dano moral coletivo em um deles, observa-se, adiante, o seu comportamento no panorama brasileiro.

\section{DANO MORAL COLETIVO NO CENÁRIO BRASILEIRO}

Em ocasião anterior, versou-se sobre os paradigmas da ressarcibilidade por responsabilização civil no direito brasileiro, em que a função reparatória e compensatória constitui o atual estado da arte da responsabilidade civil, ficando as demais, punitiva e pedagógica, quando muito, em segundo plano.

Discorreu-se no mesmo ensejo que o ressarcimento às diversificadas espécies de danos, derivados da estrutura pós-moderna de sociedade, requer inovada apreciação de modo a cogitar uma maior aplicabilidade da função punitiva, vez que, em situações como a do dano moral coletivo, as funções primárias, não raro, não atingem a devida eficácia jurídica.

$\mathrm{Na}$ realidade, depara-se hoje com o fato de que, na esfera jurídica privada, o mecanismo considerado mais efetivo de ressarcimento consiste, ainda, no pecuniário. De acordo com Michelle Amorim Sancho Souza (2104, p. 6):

[...] a ciência jurídica ainda não encontrou outra forma mais eficaz de reparação do dano extrapatrimonial [...] que não seja por meio, principalmente, da pecúnia. Somente o dano material, nessa perspectiva, é possível de se verificar, de fato, o prejuízo econômico causado ao lesado.

\footnotetext{
${ }^{8}$ No que tange ao dano moral coletivo vide: SCHREIBER, Anderson. Novos paradigmas da Responsabilidade Civil: da erosão dos filtros da reparação à diluição dos danos. 5. ed. São Paulo: Atlas, 2013.
} 
O dano, associado à ideia de responsabilidade, surge das alterações do estado originário da pessoa, seguido da redução ou perda de quaisquer dos seus bens patrimoniais ou extrapatrimoniais. Dessa maneira, o dano,

[...] seja moral, seja patrimonial, ocorre quando há uma conduta ou ausência de comportamento, que, diante do nexo causal, gera um resultado que ofende o patrimônio, individual ou coletivo, ambos protegidos pelo ordenamento jurídico, do lesado (SOUZA, 2014, p. 6).

Porém no Brasil, a imputação da obrigação jurídica de indenizar em consequência do dano estritamente moral não se sucedeu em todo o momento histórico da responsabilidade.

Até o advento da Constituição Federal de 1988, falava-se na impossibilidade de indenização em decorrência do dano moral [...]. Contudo, em pouco mais de 20 anos, houve um considerável desenvolvimento do instituto, possibilitando o reconhecimento de dano moral à pessoa física e à jurídica, nas modalidades subjetivo e objetivo, existindo uma tendência à ampliação dos danos [...] (AMARAL; SILVA, 2013, p. 322).

A ressarcibilidade por danos morais no âmbito individual, à luz do artigo $5^{\circ}$, incisos V e X, permite a indenização ao lesado pelo agente causador do dano. Em contrapartida, destoante do pacificado em dimensão privada, "[...] a aceitação da tese de dano moral coletivo [...] é motivo de acirrados debates, distante de uma uniformização [...]" (AMARAL; SILVA, 2013, p. 325).

A Constituição Federal dispõe amplamente sobre direitos de cunho social, externalizando o cuidado na defesa dos interesses difusos e coletivos ${ }^{9}$. O dano moral coletivo, defronte ao quadro no qual " [...] a proteção jurídica aos indivíduos e grupos sociais tem-se alargado na busca da garantia de uma tutela apta a alcançar o amplo leque dos interesses e direitos que lhe dizem respeito" (MEDEIROS NETO, 2007, p. 119), desempenha-se como aparato à intenção de assegurá-los, tendo em vista que:

A tutela conferida aos interesses coletivos (latu sensu) emerge da valorização e do reconhecimento das novas categorias de interesses jurídicos de feição transindividual, que são característicos da sociedade de massas, de relações e de conflitos igualmente multiplicados em dimensão coletiva, e cuja proteção tornou-se imprescindível ao equilíbrio e desenvolvimento

\footnotetext{
${ }^{9}$ Aponta Michelle Amorim Sancho Souza (2014, p. 6): “[...] o texto constitucional consagra mecanismos de tutela coletiva, ao longo do art. $5^{\circ}$, tal qual ocorre com o mandado de segurança coletivo (art. $5^{\circ}$, LXX, CF) e a ação popular (art. $5^{\circ}$, LXXIII, CF)".
} 
social, e, até mesmo, à própria preservação da vida humana e da dignidade dos indivíduos (MEDEIROS NETO, 2007, p. 98).

Isso porque "todas as considerações expendidas sobre o dano moral, até agora, referem-se à pessoa física, ao homem, ao indivíduo. Mas o Direito vem passando por profundas transformações, que podem ser sintetizadas pela palavra 'socialização"” (BITTAR FILHO, 1994, online).

O Direito Civil não sendo uma exceção a esse acontecimento na redoma jurídica,

[...] está sofrendo, ao longo do presente século, profundas e paulatinas mudanças, sob o impacto da evolução da tecnologia em geral e das alterações constantes havidas no tecido social [...]. Todas essas mutações têm direção e sentido certos: conduzem o Direito ao primado claro e insofismável do coletivo sobre o individual. Como não poderia deixar de ser, os reflexos desse panorama de mudança estão fazendo-se sentir na teoria do dano moral, dando origem à novel figura do dano moral coletivo (BITTAR FILHO, 1994, online).

A ampliação da tutela jurídica à seara extrapatrimonial das pessoas e também aos interesses de extensão coletiva significou "[...] destacado e necessário passo no processo de valorização e tutela dos direitos [...]", apresentando-se como “[...] resposta às modernas e imperativas demandas da cidadania" (MEDEIROS NETO, 2007, p. 120).

O dano moral coletivo, atendendo a urgência de socorrer a constante revelação de novos direitos e, por consecutivo, novos danos, acolhe a,

[...] necessidade do integral respeito à pessoa humana, em toda extensão dos seus interesses fundamentais, dos seus legítimos valores e de suas variadas maneiras de ser em sociedade: individualmente considerada ou reconhecida como integrante de coletividade diversas [...] albergando as diversas formas em que se possam configurar aqueles direitos [...] passíveis de ser enquadrados, pois, na variada moldura dos interesses pessoais, dos interesses coletivos, dos interesses difusos [...], dos interesses patrimoniais e dos interesses morais" (MEDEIROS NETO, 2007, p. 121-122).

Todavia, apesar de prover a defesa em combate à “[...] lesão intolerável a direitos transindividuais titularizados por uma determinada coletividade ${ }^{10}[\ldots]$ ". (MEDEIROS NETO,

\footnotetext{
${ }^{10}$ Em contributo, Xisto Tiago de Medeiros Neto (2007, p. 125-126), traz que coletividade compõe os grupos, categorias ou classes de pessoas e: "A positivação da coletividade, como titular de interesses jurídicos, reflete, em última instância, a expressão-síntese de uma das maneiras de ser das pessoas no plano social: a de partícipes de um vasto elenco de interesses comuns - portanto transindividuais - dotados de contornos peculiares, que, compartilhados, são-lhes essenciais à vida, integrando, assim, a esfera da dignidade de cada um dos respectivos membros, de maneira a ensejar a sua plena proteção jurídica". Compreendendo como valores, Carlos Alberto Bittar Filho (1994, online), pontua: "Dessas definições [...] exsurgem os fios mais importantes na composição do tecido da coletividade: os valores. Resultam eles, em última instância, da amplificação, por assim dizer, dos
} 
2007, p. 136), revela-se na doutrina e na jurisprudência constantes divergências com relação ao dano moral coletivo, colidindo os entendimentos, inclusive entre tribunais.

Assim se sinaliza no julgamento do Recurso Especial $n^{\circ} 1.464 .868 / \mathrm{MT}$, pela $2^{\mathrm{a}}$ Turma do Superior Tribunal de Justiça, interposto pelo Ministério Público em face de decisão do Tribunal de Justiça do Mato Grosso. Nele, o juízo a quo julgou pela inexistência de dano moral à coletividade, já que o prejuízo incidiu apenas a interesses individuais homogêneos ${ }^{11}$. Por outro lado, o STJ interpreta que se predomina o interesse social na tutela coletiva dos consumidores sobre os interesses individuais, originando o direito da coletividade aos danos morais coletivos, a saber:

PROCESSUAL CIVIL. RESPONSABILIDADE CIVIL. CONSUMIDOR. AÇÃO CIVIL PÚBLICA. JOGO DE AZAR ILEGAL. BINGO. INEXISTÊNCIA DE LEGISLAÇÃO QUE AUTORIZE A ATIVIDADE. INDENIZAÇÃO POR DANO MORAL COLETIVO. CABIMENTO.

1. Na hipótese dos autos, o Ministério Público Federal promoveu Ação Civil Pública visando à condenação dos réus ao pagamento de indenização por dano moral coletivo, por exploração de bingo ilegal.

2. No caso concreto, prevalece o interesse social na tutela coletiva. A necessidade de correção das indigitadas lesões às relações de consumo transcende os interesses individuais dos frequentadores das casas de jogos ilegais para dizer respeito ao interesse público na prevenção da reincidência da suposta conduta lesiva por parte dos exploradores dos jogos de azar, de onde exsurge o direito da coletividade a danos morais coletivos, ante a exploração comercial de uma atividade que, por ora, não encontra guarida na legislação.

(REsp 1.509.923/SP, Rel. Ministro Humberto Martins, Segunda Turma, julgado em 6/10/2015, DJe 22/10/2015).

3. O dano moral sofrido pela coletividade decorre do caráter altamente viciante de jogos de azar, passíveis de afetar o bem-estar do jogador e desestruturar o ambiente familiar. A responsabilidade civil é objetiva, respondendo os réus, "independentemente da existência de culpa, pela reparação dos danos causados aos consumidores" (art. 12, caput, do CDC).

4. O dano moral coletivo prescinde da comprovação de dor, de sofrimento e de abalo psicológico, pois tal comprovação, embora possível na esfera individual, torna-se inaplicável quando se cuida de interesses difusos e coletivos. (REsp 1.410.698/MG, Rel. Ministro Humberto Martins, Segunda

valores dos indivíduos componentes da coletividade. Assim como cada indivíduo tem sua carga de valores, também a comunidade, por ser um conjunto de indivíduos, tem uma dimensão ética. Mas é essencial que se assevere que a citada amplificação desatrela os valores coletivos das pessoas integrantes da comunidade quando individualmente consideradas. Os valores coletivos, pois, dizem respeito à comunidade como um todo, independentemente de suas partes. Trata-se, destarte, de valores do corpo, valores esses que não se confundem com os de cada pessoa, de cada célula, de cada elemento da coletividade. Tais valores, como se vê, têm um caráter nitidamente indivisível [...]".

${ }^{11}$ Mais detalhes sobre supradita decisão, ver em nota publicada no boletim de notícias do Superior Tribunal de Justiça: "Quarta Turma reconhece dano moral coletivo em infidelidade de bandeira praticada por posto de combustivel", datada de 29 de março de 2017. 
Turma, DJe 30/6/2015; REsp 1.057.274/RS, Rel. Ministra Eliana Calmon, Segunda Turma, DJe 26/2/2010).

5. Recurso Especial provido. ${ }^{12}$

Não obstante, situações de dissensos como esse se assiste dentro do próprio Superior Tribunal de Justiça em que, trilhando em sentido oposto ao acórdão supra, a $1^{\text {a }}$ Turma define ser “[...] inviável [...] a condenação por danos morais coletivos" 13 .

No entanto, a configuração do dano moral coletivo se anuncia como uma inevitável realidade, afigurando-se,

[...] como categoria autônomo na teoria do dano ao ter por sujeito ativo a coletividade lesada, por sujeito passivo a pessoa física, jurídica ou os próprios membros da coletividade que violam a sua própria dignidade, e o objeto consiste na tutela da dignidade coletiva, a qual não pode ser vilipendiada, notadamente, por meio da ofensa dos direitos coletivos latu sensu (SOUZA, 2014, p. 7).

A necessidade de proteção aos direitos e interesses transindividuais requer uma ressarcibilidade aos danos causados, podendo-se vislumbrá-la na configuração do dano moral coletivo. A par disso, a caracterização do dano e a condenação ao ressarcimento mediante indenização fazem refletir acerca da aplicação da função punitiva existente no dano moral como expediente ao desestimulo às práticas de atos lesivos em detrimento da coletividade, assunto o qual adiante é abordado.

\section{OS DANOS PUNITIVOS}

O dano moral coletivo tem por peculiaridade diversas críticas ${ }^{14}$ e enfrenta ampla dificuldade de ser solucionado diante do caso concreto. Quer dizer, o emprego da sistemática de responsabilidade civil por danos morais individuais aos danos à coletividade, geralmente, anuncia-se insuficiente para o efetivo alcance da proteção a direitos supraindividuais, porquanto pleitear, além do ressarcimento, uma solução que também obste a reiteração da prática de condutas lesivas.

\footnotetext{
${ }^{12}$ STJ - Resp. $\mathrm{n}^{\mathrm{o}}$. 1.464.868/SP - Min. Rel. Herman Benjamin, $2^{\mathrm{a}}$ Turma, DJ: 22.11.2016.

${ }^{13}$ STJ - AgRg no REsp. $n^{\circ}$. 1.305.977/MG - Min. Rel. Ari Pargendler, $1^{\text {a }}$ Turma, DJ: 09.04.2013.

${ }^{14}$ Xisto Tiago de Medeiros Neto (2007, p. 123) exemplifica algumas críticas que pairam no campo do dano moral coletivo tal como a própria terminologia "dano moral coletivo" em que o mais adequado seria a apropriação do termo "dano extrapatrimonial coletivo", tendo em vista o complexo de interesses metaindividuais que podem ser atingidos mediante a configuração de um dano, visto, ainda, o atual estágio de evolução da responsabilidade civil.
} 
Em verdade, a condenação pela configuração de um dano moral em escala coletiva se dá em virtude da relevância social e interesse público que comporta e, por estar intimamente relacionado à tutela dos direitos metaindividuais, exige dos ramos tradicionais do Direito uma reformulada forma de pensar que deve superar a remota concepção individualista que "[...] atendia a um padrão de vida de uma época em que inúmeras atividades não existiam, reduzindo desta forma a possibilidade de riscos para toda coletividade" (MATOS, 2002, p. 167).

Com a evidência de que os danos aos direitos transindividuais são uma nova categoria, por conseguinte, o respectivo ressarcimento que atinge a um interesse legítimo de dimensão coletiva merece distinta apreciação, dado, ainda, outros segmentos jurídicos imputarem expressiva relevância a tal bem jurídico assim como ocorre na égide penal ${ }^{15}$.

Os punitive damages, em outras palavras indenização punitiva, “[...] embora não adotada pelo legislador ordinário, vem encontrando, surpreendentemente, numerosos adeptos no Brasil, tanto em doutrina como na jurisprudência atual" (MORAES, 2009b, p. 217-218). " $\mathrm{Na}$ esteira do exemplo norte-americano, vêm fazendo estrada, em todo o mundo, os chamados punitive damages, isto é, a indenização adicional assegurada à vítima com a finalidade de punir o ofensor, e não simplesmente de compensar os danos sofridos" (SCHREIBER, 2013b, p. 211).

Observados durante séculos, entretanto, os danos punitivos tiveram sua tese fortemente defendida nos últimos anos do século XX com a aplicação de indenizações com incríveis somas contra, na maioria das vezes, grandes empresas multinacionais (DUPREE JUNIOR, 2010, p. 421) ${ }^{16}$. Com variadas denominações, os punitive damages:

Também chamado de exemplary damages, vindictive damages ou smart money, consistem na soma em dinheiro conferida ao autor de uma ação

\footnotetext{
${ }^{15}$ A importância de aproximar essas duas grandes áreas jurídicas, rompendo novamente com a dicotomia público-privada, situa-se na imposição de novas e mais severas sanções a certas condutas, a fim de que se efetivem os princípios da prevenção e precaução para que de tal modo se confira concretamente a tutela aos interesses coletivos como ambiente ecologicamente equilibrado, patrimônio cultural, relações de consumo, entre outros, expondo em mesmo sentido, para Francisco de Assis Toledo (1991, p.3): “[...] a característica do ordenamento jurídico penal que primeiro salta aos olhos é a sua finalidade preventiva: antes de punir, ou com o punir, evitar o crime".

${ }^{16}$ Nesse sentido, descreve Maria Celina Bodin de Moares (2009b, p. 219-220): "A teoria da 'pena privada' foi defendida, em meados do século XX, por Boris STARCK, em tese na qual procurava demonstrar que a 'hostilité universelle para com tal doutrina era gratuita e injustificada. Esta teoria havia sido sustentada, na França do início do século, por Louis HUGUENEY, e jazia completamente esquecida, praticamente sem adeptos, até que STARCK, particularmente influenciado pelo fundamento do risco e desejoso de oferecer, através da noção de garantia, uma nova sistematização à responsabilidade civil, atribuiu à faute (e ao dolo, bem entendido) a consequência da pena privada".
} 
indenizatória em valor expressivamente superior ao necessário à compensação do dano, tendo em vista a dupla finalidade de punição (punishment) e prevenção pela exemplaridade da punição (deterrence) opondo-se - nesse aspecto funcional - aos compensatory damages, que consistem no montante da indenização compatível ou equivalente ao dano causado, atribuído com o objetivo de ressarcir o prejuízo (MARTINSCOSTA; PARGENDLER, 2005, p. 16).

Ressalta-se que, pela doutrina, uma das críticas constatadas reside no desacerto terminológico "dano punitivo". Anderson Schreiber (2013b, p. 211), ao expor sobre a observância do instituto no recinto nacional, ostenta seu posicionamento:

Os equivocadamente chamados "danos punitivos", encontram, por toda parte, defensores, que apregoam seu caráter dissuasivo da conduta lesiva e sua necessidade diante de um cenário jurisprudencial que mantém relativamente baixos valores das reparações de danos morais.

Em mesma senda, escrevem Judith Martins-Costa e Mariana Souza Pergendler (2005, p. 16), para as quais " [...] a figura dos punitive damages pode ser apreendida, numa forma introdutória, e muito geral, pela idéia de indenização punitiva (e não 'dano punitivo', como às vezes se lê) $[\ldots] "$.

Como outrora mencionado, apesar de não serem regulamentados, os danos punitivos permitem ser reconhecidos no duplo caráter da reparação do dano moral. Anderson Schreiber (2013b, p. 211), nessa direção, relata que:

No Brasil, como em outros países de tradição romano-germânica, vive-se uma situação claramente anômala, na qual os punitive damages não vêm admitidos como parcela adicional de indenização, mas aparecem embutidos na própria compensação do dano moral. Assim, a doutrina amplamente majoritária sustenta um duplo caráter da reparação do dano moral: (i) o caráter compensatório, para assegurar o sofrimento da vítima; e (ii) o caráter punitivo para que o causador do dano, pelo fato da condenação se veja castigado pela ofensa que praticou.

Sob orientação dos regimes jurídicos do common law, para além disso instrui Carlos Alberto Bittar (1999, p. 95) que os danos punitivos se construíram em um “[...] sistema próprio de reparação de danos de caráter moral [...] destinado, de um lado, a possibilitar a afirmação dos direitos da personalidade e, de outro, a sancionar devidamente o lesante". No intuito de obstar novas práticas lesivas, “[...] daí, a distribuição dos danos indenizáveis em ordinary damages e nominal exemplay ou vindictive damages, os primeiros de grau mais 
brando e, os segundos, mais elevados [...]”, tudo “[...] para alcançar toda e qualquer violação a direitos subjetivos que provoque danos dessa ordem".

Para que haja o efetivo ressarcimento civil das lesões que irradiam efeitos a todo um conjunto de pessoas, não esporádico, faz-se cogitar a aceitação do caráter punitivo da responsabilidade civil. Transcendendo o senso de que a punição conjuga ferramenta exclusiva da responsabilidade penal, enquanto que o escopo civilístico traduziria meramente pela indenização, conforme assinala Carlos Roberto Gonçalves:

No caso da responsabilidade penal, o agente infringe uma norma de direito público. O interesse lesado é o da sociedade. Na responsabilidade civil, o interesse diretamente lesado é o privado. O prejudicado poderá pleitear ou não a reparação. (2003, p. 19).

Alcança-se que o instituto da responsabilização civil, para além da função ressarcitória, possui também os papéis preventivo e punitivo. Esse último, conquanto contestado, faz-se muito evidente nos julgados, mesmo que não diretamente discriminado e mencionado, a partir da observância de múltiplos valores do quantum indenizatório expressando verdadeiro poder criativo do juiz que, em sua função de aplicador do Direito, deve proceder o trabalho de interpretar e integrar as normas de modo a realizar a justiça quando da solução das demandas levadas ao seu conhecimento (GAMA, 2002, p. 238).

Nessa enseada, insta averiguar se, de fato, o ordenamento jurídico apresenta receptibilidade à aplicação da pena privada por meio das indenizações e se a ressarcibilidade por danos morais ocasionados em desfavor da coletividade pende maior repreensão de maneira que supere o mero ressarcimento e atue como verdadeira sanção civil privada.

\section{A (DES)NECESSIDADE DAS INDENIZAÇÕES PUNITIVAS: MERA RESSARCIBILIDADE À PENA CIVIL}

A pretensa atribuição de um cunho severamente maior à responsabilidade civil por intermédio das indenizações punitivas - danos punitivos - liga-se à preocupação de manter parcela do foco da responsabilização civil no ofensor, na sua conduta, à medida que igualmente se cuida de agasalhamento à vítima.

Em antecessor estágio, avistou-se que os punitive damages são habituais em ordens jurídicas regidas pelo common law. Cortes, como as dos Estados Unidos, cominam o dano punitivo por comportamentos atrozmente flagrantes, sendo definidos, pela maioria dos 
Estados, como um delito cometido com imprudente desprezo pelos direitos de outros seres humanos (CALLEROS, 2006, p. 69).

As indenizações punitivas precisam ser estabelecidas em prol da dissuasão em um nível que elimine a vantagem da inobservância de cumprimento de dever legal pelo responsável (COOTER, 1989, p. 1148). Além do mais, "compreender [...] a pena civil, como uma sanção punitiva de finalidade preventiva em face de ilícitos" (ROSENVALD, 2014, online).

Atenta-se que a reprovabilidade das práticas lesivas em prejuízo aos direitos transindividuais suscita uma responsabilização civil que mitigue a concretização de novas lesões, extrapolando o regime aplicável nos casos individuais.

Contrário do que argumentam numerosas críticas, Charles Calleros (2006, p. 70), pontifica que os valores das indenizações punitivas não são tão ubíquos, excessivos e injustificados quanto são constantemente retratados. E, apesar de se sujeitarem a limitações legais, mantêm-se a possibilidade de total recuperação que excede largamente o montante capital à compensação do autor pelo dano.

Maria Celina Bodin de Moraes (2009b, p. 227), de outra banda, traz à baila que graças à ausência normativa, em especial, o magistrado, durante a apreciação da situação em concreto, teria plena discricionariedade para deliberar a punição, agindo a genérica permissão do vigente Código Civil como um "cheque em branco". Nas palavras da autora:

Na verdade, a solução que se apresenta mais condizente com o instituto da pena privada, ou do caráter punitivo, na responsabilidade civil é normatizar as fattispécie merecedoras, do ponto de vista do legislador democrático, de aplicação da pena pecuniária. A questão é, evidentemente, [...] de política legislativa [...].

A solução que se avizinha, no entanto, através da inserção no novo Código Civil [...] de uma genérica autorização ao juiz para acréscimo de parcela punitiva, determinando-se que a reparação do dano moral deve constituir também "adequado desestímulo ao lesante" (parágrafo $2^{\circ}$ do artigo 944 do Código de 2002), não é, à evidencia, nem razoável, nem suficiente. Não se indicando claramente os critérios a serem levados em conta, a autorização se configura praticamente como um "cheque em branco". O magistrado continua liberado, agora expressamente, para punir como (rectius, quanto) quiser, e o lesante continua passível de sofrer uma penalidade exemplar (MORAES, 2009b, p. 227).

O instituto da responsabilidade civil, a par da finalidade punitiva-preventiva, tem potencial para ser utilizado como aparato de transformação social de forma que o alcance, indiscriminado e inconsequente, de vantagens econômicas pelos possíveis agentes da lesão 
não se sobressaia à segurança jurídica dos direitos e garantias sociais e coletivos ${ }^{17}$. Nesse ínterim, o manuseio de delicada função carece da apropriada expertise, sobretudo por predominar em regime jurídico diverso do brasileiro, sob risco de tornar-se um instrumento arbitrário e falho em suas destinações ${ }^{18}$.

Tem-se isso, haja vista que, no sistema common law, para a configuração de um dano punitivo, os julgadores tomam por apreciação alguns aspectos os quais justificam a incidência do foco sobre a conduta do ofensor (MARTINS-COSTA; PARGENDLER, 2005, p. 20). Esclarecendo como se desdobra no plano judiciário norte-americano, Judith Martins-Costa e Mariana Silva Pargendler (2005, p. 19) pontuam:

Como regra geral, salvo lei em contrário, receber punitive damages não constitui "direito subjetivo", antes dependendo da discricionariedade do júri. É bem verdade que, em algumas jurisdictions, quando há alegações e provas suficientes, os punitive damages são considerados "direitos subjetivos" sendo dever (duty) do júri concedê-los; porém, em outas, essa indenização é permitida e não "devida". Também como regra geral, não é possível a condenação em punitive damages por violação de um contrato, independente dos motivos que levaram o réu a fazê-lo, sendo seu domínio tão-somente o que, em nossa tradição, denomina-se "responsabilidade extracontratual" (law of torts).

Nesse direcionamento, Charles Calleros (2006, p. 67) descreve que, embora o common law permita os punitive damages por atos lesivos intencionais, o júri não permitirá que o inadimplemento de contrato ou a execução de uma indenização por cláusula assinalada como punitiva, sejam avaliados como danos punitivos ${ }^{19}$. Em outros termos,

[...] os punitive damages só podem ser concedidos na relação extracontratual quando provadas as circunstâncias subjetivas que se assemelham à categoria continental do dolo, quais sejam: malice, wantoness, willfuness, oppression, fraud, entre outras. A mera negligência, na ausência das circunstancias agravantes, não é razão para a condenação de punitive damages, porém a

\footnotetext{
${ }^{17}$ Para Carlos Alberto Bittar Filho (1994, online), a ampliação dos horizontes da responsabilidade civil faz-se “[...] dentro de um contexto de renovação global por que passa toda a ciência do Direito, cansada de vetustas concepções e teorias" e que ela "[...] encampa o dano moral coletivo, aumentando as perspectivas de criação e consolidação da uma ordem jurídica mais justa e eficaz".

${ }^{18}$ Judith Martins-Costa e Mariana Souza Pargendler (2005, p. 20) expõem que essa circunstância compõe uma particularidade fundamental ao balizar algumas das gerais características do instituto, tal como se executa nos Estados Unidos. Segundo as autoras, a importação do mecanismo não se apresenta suficiente, até porque nesse país se tem "[...] mais profundamente elaborada a doutrina dos punitive damages, inclusive para o efeito da crítica aos abusos correntemente praticados pela jurisprudência".

${ }^{19}$ Sem olvidar, Charles Callero (2006, p. 72) salienta que se tem identificado, nas últimas décadas, tribunais em muitos Estados que autorizam os punitive damages por "má-fé" nas violações de contrato em determinadas relações contratuais.
} 
gross negligence (negligência grave), em alguns estados, os enseja (MARTINS-COSTA; PARGENDLER, 2005, p. 19).

Ademais, Judith Martins-Costa e Mariana Silva Pargendler (2005, p. 19) apontam que, em defluência de certos abusos provenientes da atribuição concedida ao júri de fixar os punitive damages, a Suprema Corte afixou determinados " [...] parâmetros que visam minorar o que tem sido chamado de "indústria das indenizações milionárias"”. Como determinação às demais Cortes, restaram classificadas três diretrizes na fixação das indenizações punitivas, sendo tais:

I. o grau de reprovabilidade da conduta do réu [...]. Para aferir quão reprovável é a conduta, é importante, segundo a Corte, atentar-se aos seguintes fatores: (1) se o prejuízo causado foi físico ou meramente econômico; (2) se o ato ilícito foi praticado com indiferença ou total desconsideração com a saúde ou a segurança dos outros [...]; (3) se o alvo da conduta é uma pessoa com vulnerabilidade financeira; (4) se a conduta envolveu ações repetidas ou foi um incidente isolado; (5) se o prejuízo foi o resultado de uma ação intencional ou fraudulenta, ou foi um mero acidente;

II. a disparidade entre o dano efetivo ou potencial sofrido pelo autor e os punitive damages;

III. a diferença entre os punitive damages concedidos pelo júri e as multas civis autorizadas ou impostas em casos semelhantes (MARTINS-COSTA; PARGENDLER, 2005, p. 19).

Em que pese o receio do emprego da função punitiva da responsabilidade civil, a exemplaridade das indenizações sobre danos morais no Brasil, e em específico dano moral coletivo, ganha enfoque por motivos resultantes,

[...] na maior parte dos casos, da própria insuficiência das respostas oferecidas pela responsabilidade civil como mecanismo meramente ressarcitório, com montante da indenização limitado ao quantum efetivamente sofrido, segundo os cálculos advindos da Teoria da Diferença [...] (MARTINS-COSTA; PARGENDLER, 2005, p. 21).

Segundo Maria Celina Bodin de Moares (2009b, p. 219), “[...] não são poucos os que hoje afirmam que a satisfação do dano moral visa, além de atenuar o sofrimento injusto, desafrontar o inato sentimento de vingança, retribuindo o mal com mal [...]”. Porém, perante um prejuízo “[...] como a injusta lesão da esfera moral de uma dada comunidade, [...] que toma de assalto a própria cultura, em sua faceta imaterial" (BITTAR FILHO, 1994, online), 
requer-se à responsabilidade civil o fornecimento de soluções que eficazmente impactem na esfera do agente lesante, a fim de que não mais indisciplinadamente se comporte ${ }^{20}$.

Indo avante do trivial sentimento de vingança, a função punitiva pode "[...] prevenir ofensas futuras, fazendo com que o ofensor não deseje repetir tal comportamento; e servir de exemplo, para que tampouco se queira imitá-lo" (MORAES, 2009b, p. 219).

Evidente que a introdução da cultura jurídica dos punitive damages no território brasileiro, como sanção civil pecuniária, precisa comprometer-se com certas balizas no desígnio de se inobservar excessos e arbitrariedades. Dessa maneira, e de forma a também “[...] reconhecer a função punitiva e preventiva da responsabilidade civil [...]" (MARTINSCOSTA; PARGENDLER, 2005, p. 23), a jurisprudência pátria se utiliza da “[...] combinação de dois, e, por vezes, de três distintos critérios: o grau de culpa do ofensor; a condição econômica do responsável pela lesão, e o enriquecimento obtido com o fato ilícito" (MARTINS-COSTA; PERGENDLER, 2005, p. 23).

Em casos de danos que ofendam direitos e interesses juridicamente relevantes de um grupo, ou mesmo da sociedade como um todo, a lógica aplicada à ressarcibilidade do dano individual não encontra justo recinto, ensejando o dano moral coletivo “[...] tratamento próprio, específico, em relação aos danos coletivos e difusos, no plano da responsabilização do agente causador [...]” (MEDEIROS NETO, 2007, p. 155).

Congregando-se a isso, observa a indenização da sobredita espécie de dano um regime diferenciado, não se assemelhando ao dano particular. Por obedecer ao disposto no artigo 13 da Lei $n^{\circ} 7.347 / 85$ (Lei de Ação Civil Pública) ${ }^{21}$, deposita-se o imputado quantum debeatur a um fundo autenticamente regulamentado em escala nacional o qual se reverterá à reconstituição dos bens lesados.

Com vistas à sustentabilidade jurídica da tutela de direitos não somente individuais, mas, de igual modo, transindividuais, toda conduta intolerável que ocasione lesão a bens e interesses de latitude coletiva que detenha essência extrapatrimonial, impõe uma espécie de reparação que se efetive a partir da condenação em dinheiro atribuída ao lesador (MEDEIROS NETO, 2007, p.157-158) e que, por se dar nos moldes de uma indenização punitiva, faz “[...]

\footnotetext{
${ }^{20}$ Conforme assinala Robinson Bogue Mendes (2000, p. 158): “[...] aquele que paga sente a repressão da ordem legal face à sua atividade antijurídica, o que se lhe impõe como advertência, com efeito intimidatório, para que não venha mais a transgredir os valores morais de outrem".

21 "Artigo 13 - Havendo condenação em dinheiro, a indenização pelo dano causado reverterá a um fundo gerido por um Conselho Federal ou por Conselhos Estaduais de que participarão necessariamente o Ministério Público e representantes da comunidade, sendo seus recursos destinados à reconstituição dos bens lesados".
} 
refletir a função sancionatória e pedagógica que informa a natureza desse procedimento peculiar à tutela dos direitos transindividuais de maneira a não restar impune a lesão" (MEDEIROS NETO, 2007, p. 163).

Diante disso, embora se compreenda que a abordagem do dano moral coletivo dá-se, a prelúdio, à luz da responsabilidade civil justaposta as relações privadas, admite-se para as lesões aos direitos transindividuais o seu atributo punitivo que, na preocupação da salvaguarda de comunitários interesses, move incontinente doutrina e jurisprudência na ampliação de sua aceitabilidade.

\section{CONCLUSÃO}

No cenário de globalização e sociedade de massa, dá-se margem a lesões aos inúmeros interesses legítimos de uma coletividade, assim como aos direitos transindividuais. Nisso, a espécie autônoma dano moral coletivo encontra campo vasto à sua configuração. Dessa forma, a imputação da responsabilidade civil com finalidade punitiva no cenário brasileiro se manifesta plausível, ante a paulatina aceitação da doutrina e jurisprudência, bem como uma solução eficiente a esses inéditos dilemas, pois a determinação da pena civil permite incutir no responsável pela ofensa uma rigorosa punição que, conjuntamente, visa a prevenção contra a manutenção de outras práticas.

Em sede de direitos difusos e coletivos, observa-se que a ressarcibilidade pelo dano moral coletivo - aquele oriundo de condutas ofensivas aos direitos transindividuais pertencentes a uma determinada coletividade - possui um regime diferenciado e que a imposição das indenizações condizentes aos danos morais individuais mostra-se insatisfatória. Sendo assim, na esteira da releitura da responsabilidade civil, as penas privadas, ao proporcionarem uma diferente perspectiva de finalidade ao instituto que não só a reparação/compensação, possibilitam afirmar a salvaguarda desses direitos e sancionam devidamente o lesante.

Constata-se que no âmbito jurídico brasileiro precisa-se, sim, de um maior preparo e compreensão dos punitive damages. Porém, inclusive a jurisprudência acautela-se quanto à evitabilidade de abusos e extravagâncias. Assim, a interpretação da doutrina comparada faz-se visível na atuação dos tribunais, principalmente quando da adoção de determinados critérios à fixação das respectivas indenizações. 
A responsabilidade civil, integrada desse contemporâneo panorama da finalidade punitiva aplicável por meio do ressarcimento, tem capacidade de ser empregada como instrumento de modificação e progresso social. De mesma sorte, nota-se que, mediante o acolhimento da pena civil, pode-se alcançar a sustentabilidade jurídica dos direitos e interesses legítimos difusos e coletivos em face dos efeitos negativos e inevitáveis do crescente processo tecnológico e biotecnológico, como também, a prevenção da reiteração de condutas negativamente exemplares dos ofensores que, pelos lucros econômicos, apresentamse tão evidentes diuturnamente.

\section{REFERÊNCIAS}

AMARAL, Ana Cláudia Corrêa Zuin Mattos do; SILVA, Fernando Moreira Freitas da. "Dano moral coletivo e sociedade globalizada: o estado atual da arte e perspectivas futuras. In: XXII Congresso Nacional do Conselho Nacional de Pesquisa e Pós-graduação em Direito (CONPEDI). p. 319-335, São Paulo, 2013.

BITTAR, Carlos Alberto. Reparação Civil por danos morais. 3 ed. São Paulo: Editora Revista dos Tribunais, 1999.

BITTAR FILHO, Carlos Alberto. Do dano moral coletivo no atual contexto jurídico brasileiro. 1994. Disponível em: < http://egov.ufsc.br/portal/sites/default/files/anexos/3088133349-1-PB.pdf >. Acesso em: 10 de abr. 2017.

BRASIL. Lei $n^{\circ} 7.347$ de 1985. Disponível em: < http://www.planalto.gov.br/ccivil_03/leis/L7347orig.htm> Acesso em: 9 mai. 2017.

Superior Tribunal de Justiça. Agravo Regimental no Recurso Especial $n^{o}$ 1305.977/MG. Agravanete: Ministério Público Federal. Agravado: Município de Uberlândia. Relator: Ministro Ari Pargendler. Brasília, 09 abr. 2013.

Superior Tribunal de Justiça. Recurso Especial $n^{\circ}$ 1.464.868/MT. Recorrente: Ministério Público do Mato Grosso. Recorrido: Attilio Grisólia Filho e outro. Relator: Ministro Luis Felipe Salomão. Brasília, 13 dez. 2016.

. Superior Tribunal de Justiça. Recurso Especial $n^{o}$. 1.464.868/SP. Recorrente: Ministério Público Federal. Recorrido: A K do Guarujá Clube Recreativo. Relator: Herman Benjamin. 22 nov. 2016.

. "Quarta Turma reconhece dano moral coletivo em infidelidade de bandeira praticada por posto de combustível”. In: Boletim de Notícias do Superior Tribunal de Justiça. 
Disponível

em:<http://www.stj.jus.br/sites/STJ/default/pt_BR/Comunica\%C3\%A7\%C3\%A3o/noticias/N ot $\% \mathrm{C} 3 \%$ ADcias/Quarta-Turma-reconhece-dano-moral-coletivo-em-infidelidade-de-bandeirapraticada-por-posto-de-combust\%C3\%ADvel> Acesso em: 13 mai. 2017.

. V Jornada de Direito Civil - enunciados. Disponível em <

http://www.cjf.jus.br/cjf/CEJ-Coedi/jornadas-cej/enunciados-aprovados-da-i-iii-iv-e-vjornada-de-direito-civil/jornadas-de-direito-civil-enunciados-aprovados> Acesso em 30 abr. 2017.

CALLEROS, Charles. "Punitive Damages, Liquidated Damages, and Clauses Penales in Contract Actions: A Comparative Analysis of the American Common Law and the French Civil Code". In: Brooklyn Journal of International Law Review. v. 32, 2006. Disponível em: < http://brooklynworks.brooklaw.edu/bjil/vol32/iss1/2> Acesso em: 10 abr. 2017.

CAVALIERI FILHO, Sérgio. Programa de responsabilidade civil. 10. ed. São Paulo: Atlas, 2012.

COOTER, Robert. "Punitive damages for deterrence: when and how much?". In: Alabama Law Revew. v. 40, n. 3, Spring: 1989.

DINIZ, Maria Helena. Curso de direito civil brasileiro: responsabilidade civil. 15. ed. São Paulo: Saraiva, 2001.

DUPREE JUNIOR, Thomas H. "Punitive Damages and the Constitution". In: Lousiana Law Review. v. 70, n. 2, 2010. Disponível em:

<http://digitalcommons.law.lsu.edu/lalrev/vol70/iss2/3> Acesso em: 05 abr. 2017.

FACHIN, Luiz Edson. Teoria crítica do Direito Civil. Rio de Janeiro: Renovar, 2000.

GAMA, Guilherme Calmon Nogueira da. "Critérios para a fixação da reparação do dano moral". In: Grandes temas da atualidade: dano moral. Coord. Eduardo de Oliveira Leite. Rio de Janeiro: 2002.

GONÇALVES, Carlos Roberto. Responsabilidade civil. 8. ed. São Paulo, Saraiva, 2003.

MARTINS-COSTA, Judith; PARGENDLER, Mariana Souza. "Usos e abusos da função punitiva (punitive damages e o Direito brasileiro)". In: Revista CEJ. n. 28, p. 15-32, jan./mar. Brasília, 2005. 
MATOS, Eduardo Lima de. Dano Moral Ambiental: "Uma nova perspectiva de responsabilidade civil”. In: Grandes temas da atualidade: dano moral. Coord. Eduardo de Oliveira Leite. Rio de Janeiro: 2002.

MEDEIRAS NETO, Xisto Tiago de. Dano moral coletivo. 2. ed. São Paulo: LTr, 2007.

MENDES, Robinson Bogue. Dano moral e obrigação de indenizar: critérios de fixação do quatum. Campo Grande: UCDB, 2000.

MORAES, Maria Celina Bodin de. "A constitucionalização do direito civil e seus efeitos sobre a responsabilidade civil”. In: Revista Direito, Estado e Sociedade. v. 9, n. 29, p. 233 258, jul./dez., 2006a.

Danos à pessoa humana: uma leitura civil-constitucional dos danos morais. Rio de Janeiro: Renovar, 2009b.

ROSENVALD, Nelson. As funções da responsabilidade civil. Vídeo publicado em 24 de setembro de 2014. Disponível em: < https://www.youtube.com/watch?v=cZ6WupRFdWU> Acesso em 12 mai. 2017.

SCHREIBER, Anderson. "Novas tendências da responsabilidade civil brasileira". Revista Trimestral de Direito Civil. Rio de Janeiro: Padma, v. 22, p. 45-69, abr./jun. 2005a.

Novos paradigmas da responsabilidade civil: da erosão dos filtros de reparação à diluição dos danos. 5. ed. São Paulo: Atlas, 2013b.

SOUZA, Michelle Amorim Sancho. "A concretização da dignidade coletiva por meio do dano moral coletivo". In: Sapientia - Revista de Direito do Centro Universitário Estácio de Sá de Belo Horizonte. vol. 2, no. 2, p. 14, Belo Horizonte, 2014.

TEPEDINO, Gustavo. “A evolução da Responsabilidade Civil no Direito Brasileiro e suas controvérsias na atividade estatal" In: Temas de Direito Civil. 3. ed. atual. Rio de Janeiro: Renovar, 2004.

TOLEDO, Francisco de Assis. Princípios básicos de direito penal. 4. ed. São Paulo: Saraiva, 1991. 